\title{
EDUKASI KONTEN PORNOGRAFI DALAM PENGGUNAAN GADGET DI SEKOLAH MENENGAH KEJURUAN (SMK) MEDIKA SAMARINDA
}

\author{
Ferry Fadzlul Rahman ${ }^{1 *}$, M. Ardan², Herni Johan ${ }^{3}$ \\ ${ }^{\text {I} P r o g r a m ~ S t u d i ~ K e s e h a t a n ~ M a s y a r a k a t, ~ F a k u l t a s ~ K e s e h a t a n ~ d a n ~ F a r m a s i, ~ U n i v e r s i t a s ~ M u h a m m a d i y a h ~ K a l i m a n t a n ~}$ \\ Timur, Samarinda, Indonesia \\ ${ }^{2}$ Departemen Manajemen Rumah Sakit, Sekolah Tinggi Ilmu Kesehatan Mutiara Mahakam, Samarinda, Indonesia \\ ${ }^{3}$ Departemen Kebidanan, Sekolah Tinggi Ilmu Kesehatan Mutiara Mahakam, Samarinda, Indonesia \\ *Penulis Korespondensi: ffr607@umkt.ac.id
}

\begin{abstract}
Abstrak
Teknologi tidak dapat dipisahkan dari pembangunan manusia. Remaja telah beradaptasi dengan relatif mudah terhadap tehnologi informasi perilaku pornografi pada remaja laki-laki dan perempuan didorong oleh beberapa factor salah satunya adalah penggunaan internet melalui handpone. Kegiatan pengabdian masyarakat ini bertujuan untuk meningkatkan pengetahuan remaja mengenai edukasi konten pornografi dalam penggunaan gadget pada siswa-siswi SMK Medika Samarinda yang diikuti oleh 45 responden. Sebelum dilaksanakan penyuluhan terlebih dahulu melaksanakan Focus Gorup Discussion (FGD) bersama pihak Yayasan dan Kepala Sekolah. Hasil menunjukkan bahwa pengetahuan remaja meningkat setelah dilaksanakan penyuluhan $(\mathrm{p}=0,001<0,05)$ dengan rata-rata 5,7 menjadi 6,4 . Selain itu juga dihasilkan komitmen bersama dengan pihak stakeholder sekolah mengenai pengawasan penggunaan gadget dilingkungan sekolah.
\end{abstract}

Kata Kunci : Edukasi; Pornografi; Gadget.

\begin{abstract}
Technology cannot be separated from human development. Adolescents have adapted relatively easily to information technology on pornography behavior in adolescent boys and girls driven by several factors, one of which is the use of the internet via mobile phones. This community service activity aims to increase teenagers' knowledge about the education of pornographic content in the use of gadgets to students of SMK Medika Samarinda, which was attended by 45 respondents. Before the counseling was carried out, a Focus Focus Discussion (FGD) is held together with the Foundation and the Principal. The results showed that the knowledge of adolescents increased after the outreach $(p=0.001<0.05)$ with an average of 5.7 to 6.4. Furthermore, there was also a joint commitment with school stakeholders regarding the supervision of the use of gadgets in the school environment.
\end{abstract}

Keywords : Education; Pornography; Gadget.

\section{PENDAHULUAN}

Era globalisasi di bidang telekomunikasi dan transportasi ditandai dengan pertumbuhan media komunikasi yang cepat. Perkembangan di bidang komunikasi seperti jaringan telepon, jaringan internet, koran dan televisi hingga masuk ke desa, sehingga berdampak kepada peningkatan intensitas dan kualitas dari interaksi sosial (Brownson, Samet, \& Bensyl, 2017). Sehingga dapat di simpulkan bahwa tehnologi adalah sebagai sarana masuknya dunia modern di masyarakat.

Teknologi tidak dapat dipisahkan dari pembangunan manusia. Perkembangan teknologi selalu mengikuti secara proporsional pembangunan ilmu pengetahuan manusia, selain itu kemajuan teknologi menjadi standart atau tolak ukur kemajuan dunia modern di masyarakat sehingga masyarakat selalu erat dengan teknologi (Knutson \& de Soysa, 2019). Perkembangan dunia teknologi informasi yang demikian pesatnya telah membawa manfaat luar biasa bagi kemajuan peradaban umat manusia.Kegiatan komunikasi yang sebelumnya menuntut peralatan yang begitu rumit, kini relatif sudah digantikan oleh perangkat mesin-mesin otomatis. Sistem kerja alat teknologi telah mengalihfungsikan tenaga otot manusia dengan pembesaran dan percepatan yang menakjubkan.

Secara sosiologis teknologi adalah salah satu aspek yang mempengaruhi setiap aspek tingkah laku dan tindakan manusia, teknologi mampu mengubah pola interaksi hubungan antara manusia, kehadiran dari teknologi adalah sesuatu yang tidak bisa di pungkiri dari aktivitas kehidupan manusia (Winetrobe, 2011). Hal ini mebuat perubahan pola interaksi antara manusia yang membuat seseorang bisa sangat terbuka atas semua perolehan informasi. 
Remaja telah beradaptasi dengan relatif mudah terhadap tehnologi informasi (Jati et al., 2019) dan komunikasi yang memungkinkan mereka untuk mengeksplorasi, bereksperimen dan mengapresiasikan dan menantang batas jauh dari pengawasan orang tua (Rahman, 2019), proses pembentukan identitas remaja difasilitasi kebebasan memilih dan mengexploitasi pengetahuan mengenai seksualitas (Van Zanten et al., 2016) Keinginan untuk selalu berhubungan dan berkomunikasi dengan teman sebaya untuk mengekspresikan diri dan berbagi pengalaman telah memotivasi remaja untuk memanfaatkan berbagai alat komunikasi dengan individu maupun kelompok baik secara real time maupun respon yang tertunda

Data hasil skrining anak sekolah dasar yang dilakukan oleh Kementrian Kesehatan Republik Indonesia pada akhir tahun 2017 dan dipublikasikan pada Maret 2018 tentang skrining keterpaparan adiksi pornografi, sebanyak $91,58 \%$ dari 6.000 anak telah terpapar pornografi. Sedangkan $6,30 \%$ mengalami adiksi pornografi ringan dan $0,07 \%$ sudah mengalami adiksi pornografi berat (Rochmawati \& Arsyati, 2019). Penelitian End Child Prostitution, Child Pornography and Trafficking of Children for Sexual Purposes (ECPAT) Indonesia, menunjukkan di 6 Kabupaten atau Kota ditemukan fakta bahwa anak-anak terpapar pornografi melalui smartphone (Eka, 2019).

Hasil study (Hardani et.al, 2018) menunjukkan bahwa perilaku pornografi pada remaja laki-laki dan perempuan didorong oleh beberapa factor salah satunya adalah penggunaan internet melalui handpone. Beberapa penelitian lain tentang perilaku pornografi telah menyoroti kemajuan tehnologi sebagai alasan utama masalah bagi remaja, serta hasil penelitian menemukan perilaku pornografi seperti seks bebas dan aseksual di kalangan remaja di identifikasi dari seberapa sering remaja terpapar konten pornografi, sehingga jika dapat teridentifikasi lebih awal maka dapat mencegah perilaku tersebut mengarah ketingkat yang lebih parah (Hardani et.al, 2018; Muusses et.al, 2015; Rice et.al., 2015; Van Zanten et.al., 2016; Wu et.al, 2015).

Kehadiran gadget sangat dibutuhkan manusia sebagai alat komunikasi dan sangat membantu karena ukurannya yang semakin bervariasi sehingga mudah dibawa kemana saja. Meskipun demikian, disatu sisi dengan adanya gadget, dapat mengakses berbagai informasi dengan sangat cepat, namun disisi lain sangat memprihatinkan karena gadget dapat menimbulkan dampak negatif bagi generasi muda khususnya para pelajar. Berdasarkan data Statistik, pengguna gadget di Indonesia pada 2019 sekitar 92 juta, naik $2 \%$ dari tahun sebelumnya. Angka ini akan merayap pelan hingga empat tahun ke depan yang diramal sekitar $33 \%$ dari total penduduk Indonesia. Pertumbuhan pengguna gadget di Indonesia tergolong tinggi. Untuk pemakai muda berusian 18-34 tahun meningkat dari 39\% menjadi $66 \%$ dari 2015-2018. Sedangkan untuk pengguna gadget berusia di atas 50 tahun, juga naik dari 2\% pada 2015 menjadi 13\% pada 2018 (Alfarizi, 2019).
Menurut data Asosiasi Penyelenggara Jasa Internet Indonesia (2019) menyatakan bahwa mayoritas penduduk di Kalimantan telah menggunakan internet. Sedangkan Kalimantan Timur merupakan penetrasi kedua terbesar mencapai $67,8 \%$ dari total penduduk setelah Kalimantan Barat (80\%), Kalimantan Selatan $(76,4 \%)$ dan Kalimantan Tengah $(70 \%)$. Sedangkan jenis media sosial yang paling sering digunakan adalah Youtube mencapai 88\%, whatsapp 84\% dan Facebook $82 \%$ (APJII, 2020). Tingginya penggunaan gadget di Indonesia melalui media-media sosial dan internet memungkinkan para penggunanya khususnya kalangan pelajar yang memiliki rasa ingin tahu yang lebih besar akan berpotensi untuk mengakses pornografi, sehingga diperlukan suatu upaya pemberian edukasi kepada pelajar tentang dampak atau pengaruh konten-konten pornografi.

Kegiatan pengabdian masyarakat ini, kepala sekolah guru dan pengurus yayasan diajak untuk berdiskusi dalam focus group discussion (FGD) guna mengenal masalah dan mencari pemecahan masalah pornografi bagi siswa, setelah itu siswa berikan pengetahuan mengenai efek bahaya dari menonton pornografi melalui gadget atau handphone. Harapannya dengan FGD Bersama guru dan pimpinan serta pemberian pengetahuan kepada siswa SMK Medika masalah kecanduan menonton pornografi melalui gadget dapat berkurang serta siswa yang memiliki pengetahuan dapat menjadi peer Educator dan agen perubah di lingkungan masing-masing.

\section{BAHAN DAN METODE}

Dalam melaksanakan kegiatan pengabdian kepada masyarakat dilakukan di SMK Medika Samarinda di Jalan Padat Karya No.34, Bengkuring Luar, Kelurahan Sempaja Timur, Kota Samarinda, Provinsi Kalimantan Timur yang dilaksanakan pada bulan Januari 2019. Peserta merupakan siswa-siswi kelas X yang berjumlah 45 orang. Kegiatan ini dilakukan sebagai upaya atau cara untuk memberikan edukasi kepada remaja tentang dampak konten pornografi dalam penggunaan gadget sehingga meningkatkan pengetahuan dan pemahaman remaja dalam mengatisipasi efek yang akan ditimbulkan.

Tahapan pelaksanaan kegiatan dilakukan sebagai berikut:

a. Focus Group Discussion (FGD)

Ditahap pertama dalam mengidentifikasi permasalahan remaja terkait konten pornografi dalam penggunaan gadget disekolah, tim melaksanakan FGD kepada pengurus Yayasan dan Kepala Sekolah SMK Medika Samarinda sebagai mitra pengabdian ini.

b. Edukasi/Penyuluhan

Edukasi dilakukan untuk memberikan pemahaman dan meningkatkan pengetahuan siswa-siwi SMK Medika Samarinda tentang dampak konten pornografi dalam penggunaan gadget. Partisipasi peserta dilakukan dengan cara memberikan kuesioner untuk mengetahui pengetahuan remaja 
sebelum penyuluhan (pre-test) dan setelah penyuluhan (post-test). Adanya peningkatan nilai post-test setalah dilakukan penyuluhan merupakan indicator penilaian keberhasilan pelaksanaan penyuluhan.

Rancangan pelaksanaan kegiatan seperti gambar diabwah ini:

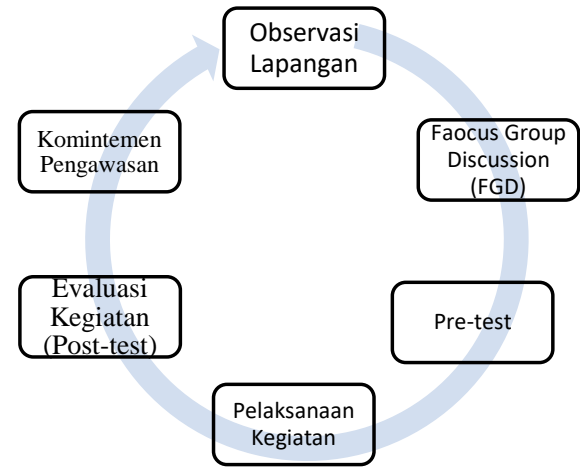

Gambar 1. Alur/proses pelaksanaan kegiatan.

\section{HASIL DAN PEMBAHASAN}

Pelaksanaan pengabdian tentang edukasi konten pornografi dalam penggunaan gadget di SMK Medika Samarinda diikuti oleh 45 peserta yang berusia 16-18 tahun. Kegiatan ini dilakukan dengan beberapa tahap dimulai dengan melaksanakan Focus Group Discussion (FGD), melaksanakan pretest, Ekukasi dampak konten pornografi dan terakhir melaksanakan posttest.

Kegiatan yang berkaitan dengan FGD telah banyak digunakan untuk mendapatkan informasi sesuai dengan keinginan, kebutuhan, sudut pandang, konsep atau ide, kepercayaan dan pengalaman yang dikehendaki. Dengan diketahuinya masalah dan potensi yang dimiliki untuk menyelesaikan masalah, maka masalah tersebut dapat diselesaikan dengan segera serta juga dapat diterapkan untuk menggali informasi sesuai dengan kebutuhan yang diinginkan (Paramita \& Kristiana, 2013).

Dalam menilai pengetahuan peserta tentang konten pornografi maka sebelum dilakukan penyuluhan terlebih dahulu setiap peserta diberikan kuesioner (pretest) dan setelah penyuluhan (post-test). Manfaat dalam melaksanakan metode pretest-posttest telah banyak dilakukan sebelumnya diantaranya memberikan gambaran keberhasilan peningkatan pengetahuan siswa-siswi tentang kegiatan penyuluhan kesehatan dari rata-rata 44,67 menjadi 89,78 (Damayanti et.al, 2017).

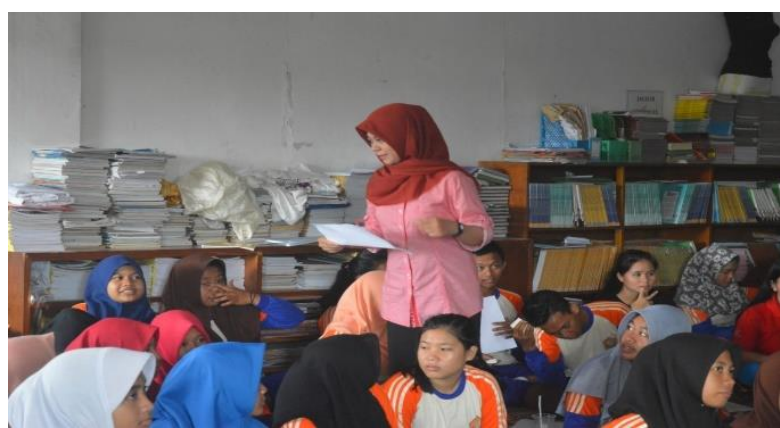

Gambar 2. Pre-Post Test.

Deskriptif dari hasil pengabdian ini dapat dilihat pada tabel berikut:

Tabel 1. Distribusi Berdasarkan Karakteristik

Responden.

\begin{tabular}{lcc}
\hline \multicolumn{1}{c}{ Hasil Statistik } & f & \% \\
\hline Jenis Kelamin & & \\
Laki-Laki & 18 & 40 \\
$\begin{array}{l}\text { Perempuan } \\
\text { Lama Menggunakan Gadget/hari }\end{array}$ & 27 & 60 \\
< 3 jam & 16 & 35,6 \\
$3-8$ jam & 18 & 40 \\
$>\quad 8$ jam & 11 & 24,4 \\
Pernah Mengakses Konten Pornografi & & \\
Ya & 15 & 33,3 \\
Tidak & 30 & 66,7 \\
$\begin{array}{l}\text { Pengetahuan Sebelum Penyuluhan } \\
\text { Baik }\end{array}$ & 10 & 22,2 \\
Sedang/Cukup & 35 & 77,8 \\
$\begin{array}{l}\text { Pengetahuan Sebelum Penyuluhan } \\
\text { Baik }\end{array}$ & & \\
Sedang/Cukup & 20 & 44,4 \\
\hline
\end{tabular}

Dari tabel 1 diatas menunjukkan bahwa karakteristik responden dalam pengabdian ini adalah mayoritas berjenis kelamin perempuan $27(60 \%)$ dan laki-laki $18(40 \%)$. Sedangkan lama waktu menggunakan gadget dalam sehari adalah antara 3-8 jam/hari sebanyak 18 orang $(40 \%)$, < 3 jam sebanyak 16 orang $(35,6 \%)$ dan $>$ 8 jam perhari sebanyak 11 orang $(24,4 \%)$. Kemudian responden yang pernah mengakses konten pornografi sebanyak 15 orang $(33,3 \%)$ dan yang tidak pernah sebanyak $66,7 \%$.

Hasil distribusi tersbut juga menunjukkan bahwa pengetahuan pelajar tentang dampak konten pornografi sebelum dilakukan penyuluhan yang memiliki pengetahuan sedang/cukup sebanyak 35 orang $(77,8 \%)$ dan menurun setelah penyuluhan sebasar $22,5 \%$. Sedangkan pengetahuan sebelum baik sebelum penyuluhan sebanyak 10 orang $(22,2 \%)$ meningkat setealah penyuluhan sebesar $(22,2 \%)$.

Ditinjau dari hasil analisis uji t sampel berpasangan dari pengabdian ini juga memberikan gambaran keberhasilan dari kegiatan penyuluhan dengan distribusi rata-rata pengetahuan responden sebelum dan sesudah penyuluhan dapat dilihat pada tabel berikut: 
Tabel 2. Perbedaan rata-rata pengetahuan responden Sebelum dan Sesudah Penyuluhan Tahun 2020.

\begin{tabular}{cccc}
\hline $\begin{array}{c}\text { Statistik } \\
\text { Pengetahuan }\end{array}$ & Pretest & Posttest & $\begin{array}{c}\text { Nilai } \\
\mathbf{p}\end{array}$ \\
\cline { 1 - 3 } Min-Max & $30-80$ & $30-90$ & \\
\cline { 1 - 3 } Mean \pm SD & $5,7 \pm 1,2$ & $6,4 \pm 1,5$ & \\
\hline
\end{tabular}

Tabel 2 menunjukkan bahwa terjadi peningkatan ratarata pengetahuan responden setelah dilakukan kegiatan penyuluhan, yaitu 5,7 menjadi 6,4 dengan nilai pretest minimum - maksimu (30-80) setelah penyuluhan nilai posttest minimum maksimum (30-90).

Berdasarkan tabel hasil uji $\mathrm{t}$ berpasangan terlihat bahwa nilai $\mathrm{p}=0,001<0,05$ yang bermakna terdapat peningkatan pengetahuan responden sebelum penyuluhan dengan sesudah penyuluhan. Selama pelaksanaan kegiatan antusias siswa-siswi sangat tinggi dalam mengikuti kegiatan penyuluhan.

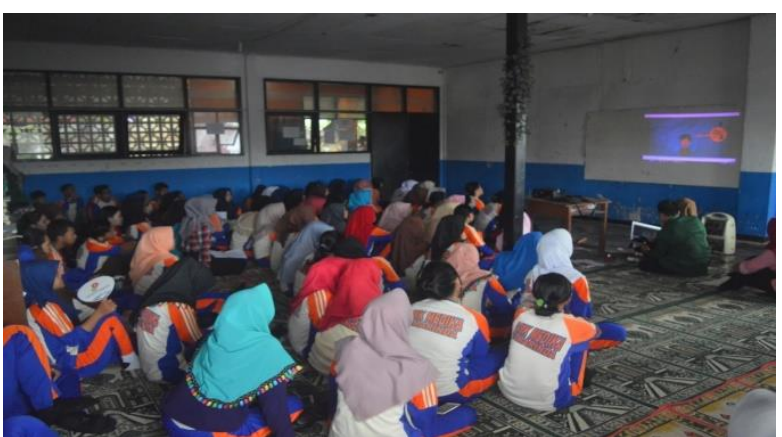

Gambar 3. Edukasi Tentang Konten Pornografi.

Dalam memanfaatkan teknologi terutama teknologi informasi dan komunikasi sangat identik dengan generasi millineal saat ini, berbading dengan generasi jauh sebelumnya. Manfaat teknologi yang semakin canggih namun juga memiliki dampak yang negatif dengan semakin terbukanya akses internet dalam gadget yang mampu menampilkan segala hal berupa gambar maupun video. Selain itu pula mampu menurunkan daya konsentrasi dan ketergantungan untuk mengejakan sesuatu sehingga berdampak pada psikologis terutama krisis kepercayaan diri. Hal ini sejalan dengan penelitian Santosa (2015) menyatakan bahwa perkembangan internet dan media sosial memungkinkan percepatan informasi secara cepat sehingga penyebaran informasi yang mengandung unsur konten foto dan atau video pornografi lebih tidak terbatas dan semakin luas. Pelajar yang menggunakan teknologi media untuk menonton pornografi, menjadi ketergantungan, dan akhirnya mengaplikasikan kegiatan seksual tersebut. Dengan melalui internet, bukan hanya konten negative tapi juga semua dapat menawarkan dalam hal positif sepeti materi-materi pelajaran kepada siapa saja, kapan saja, dan dimana saja. Para siswa dapat mengakses materimateri pelajaran selama tujuh hari seminggu, 24 jam sehari.

Potensi pelajar terhadap akses konten pornografi pada gadget dapat diamati dengan semakin canggihnya perangkat seluler yang dimiliki maka semakin besar peluang untuk terpapar konten pornografi. Teknologi yang diciptakan oleh manusia, namun pada akhirnya teknologi dapat membentuk perilaku manusia (Rachmaniar Et.al, 2018). Sebelum adanya gadget, akses terhadap terhadap konten pornografi sangat terbatas, konten pornografi sebatas film dalam bentuk DVD, VCD dan sebagainya yang membutuhkan usaha yang lebih untuk mendapatkan, dalam pengertian lain remaja secara sadar dalam mengakses konten pornografi. Namun saat ini dengan adanya gadget yang memiliki berbagai kecanggihan dan fitur yang lengkap, paparan pornografi lebih luas dan massif, sehingga pelajar dapat terpapar secara tidak sengaja.

Jika pengguna gadget para pelajar dibiarkan dalam mengakses konten pornografi tanpa diberikan edukasi maka akan menjadi pelanggan seumur hidup dan mengalami kerusakan PRC (Pre Frontal Cortex) yakni bagian otak yang berfungsi untuk pusat pertimbangan dan pengambilan keputusan. Awalnya pelajar akan mengalami gangguan konsentrasi, menurun kemampuan dalam menimbang benar dan salah, serta berkurangnya kemampuan dalam mengambil sebuah keputusan. Dampak lebih lanjut dapat ditimbulkan adalah penyimpangan seksual atau perilaku tindakan kekerasan seksual. Sebagaimana Ambarsari (2018) menyatakan bahwa media elektronik secara individu dapat berperan secara signifikan terhadap perilaku seksual.

Setalah pengabdian ini dapat diketahui bahwa media elektonik seperti gadget semakin diminati dan berperan dalam meningkatnya pengetahuan remaja tentang pornografi, sehingga dihasilkan komitmen bersama stakeholder untuk memberikan pengawasan penggunaan gadget di lingkungan sekolah.

\section{KESIMPULAN}

Pelajar merupakan bagian dari generasi millennial yang identik dengan kemampuan yang lebih dalam memanfaatkan teknologi diantaranya teknologi informasi dan komunikasi dibandingkan generasigenerasi yang jauh diatasnya. Disamping itu manfaat positif dari teknologi sangat banyak, namun juga sejumlah dampak negative yang ditimbulkan juga mengiringi perkembangan teknologi saat ini.

Dalam kontek pengabdian masyarakat ini, edukasi yang diberikan adalah dampak negative yang terkait dengan penggunaan gadget dan potensi terbukanya akses terhadap maraknya konten-konten pornografi. Pengetahuan dari para responden menunjukkan bahwa tingkat penggunaan gadget telah merupakan kebiasaan dan memiliki efek kecanduan sehingga lebih dari 8 jam perhari dihabiskan waktu untuk menggunakan gadget yang memiliki fitur lebih canggih dan lengkap sehingga sebagian diantaranya bukan hanya sebagai untuk mengakses tugas-tugas sekolah namun juga ada yang mengakses konten-konten yang sebenarnya mereka tidak kehendaki yakni konten pornografi. Namun seiring dengan penggunaannya, pengetahuan para 
responden tentang bahaya atau dampak yang ditimbulkan akibat kebiasaan mengakses konten tersebut masih tergolong rendah. Maka setelah dilakukan edukasi mengenai dampak konten pornografi dalam penggunaan gadget tingkat pengetahuan siswasiswi mengalami peningkatan yang lebih baik dari sebelumnya,

Kegiatan edukasi mengenai konten pornografi dalam penggunaan gadget yang menunjukkan adanya peningkatan tingkat pengetahuan siswa-siswi di SMK Medika Samarinda dengan pengetahuan yang baik meningkat dari $22,2 \%$ menjadi $44,4 \%$ serta dihasilkan komitmen bersama untuk pengawasan penggunaan gadget dilingkungan sekolah yang merupakan upaya dalam mengurangi kecanduan para pelajar terhadap konten pornografi, serta dengan harapan para pelajar mengedukasi diri sendiri dampak yang ditimbulkan karena terbiasa mengkonsumsi konten pornografi yang mengakibatkan perilaku tindak kekerasan seksual dalam jangka panjang akan terjadi dimasa yang akan datang.

\section{DAFTAR PUSTAKA}

Alfarizi, M.K., (2019). Survey Kepemilikan Smartphone, Indonesia Peringkat Ke-24. Jakarta: Tempo.co

Ambarsari, P.I. (2018). Peran Media Dengan Konten Pornografi Terhadap Perilaku Seksual Remaja. Surakarta : $1-12$

APJII. (2019). Penetrasi Internet Kalimantan Timur Terendah Kedua di Kalimantan. Jakarta. Databoks.

Brownson, R. C., Samet, J. M., \& Bensyl, D. M. (2017). Applied epidemiology and public health: are we training the future generations appropriately? Annals of Epidemiology, 27(2), 77-82. doi:10.1016/j.annepidem.2016.12.002

Damayanti, N. A., Pusparini M., Djannatun T., \& Ferlianti R. (2017). Metode Pre-Test dan PostTest Sebagai Salah Satu Alat Ukur Keberhasilan Kegiatan Penyluhan Kesehatan Tentang Tuberkulosis di Kelurahan Utan Panjang Jakarta Pusat. Prosiding SNaPP Kesehatan, 3 (1), 144-150.

Eka, P. (2019). Catatan Akhir Tahun Kasus Kekerasan Terhadap Anak. Majalah Kartini.

Hardani, R., Hastuti, D., \& Yuliati, L. N. J. J. o. C. D. S. (2018). Pornography behavior of junior high school student. 3(1), 15-27.

Jati, H. F., Darsono, S. N. A. C., Hermawan, D. T., Yudhi, W. A. S., Rahman, F. F. J. J. E., \& Pembangunan, S. (2019). Awareness and Knowledge Assessment of Sustainable Development Goals Among University Students. 20(2), 163-175.

Knutson, A., \& de Soysa, I. (2019). Does social globalisation through access to information communication technologies drive obesity among youth? An empirical analysis, 19902013. Global Public Health, 14(12), 19111926. doi:10.1080/17441692.2019.1652335

Muusses, L. D., Kerkhof, P., \& Finkenauer, C. J. C. i. H. B. (2015). Internet pornography and relationship quality: A longitudinal study of within and between partner effects of adjustment, sexual satisfaction and sexually explicit internet material among newly-weds. 45, 77-84.

Paramita, A., \& Kristiana L. (2013). Teknik Focus Group Discussion Dalam Penelitian Kualitatif. Buletin Penelitian Sistem Kesehatan, 16 (2), 117 - 127.

Rahman, F. F. (2019). Pengantar Ilmu Kesehatan Masyarakat: Introduction to Public Health (Vol. 1): Gosyen publishing.

Rachmaniar, Prihandini P., Janitra P.A, (2018). Perilaku Penggunaan Smartphone dan Akses Pornografi di Kalangan Remaja Perempuan. Jurnal Komunikasi Global. 7 (1), 1-11.

Rice, E., Winetrobe, H., Holloway, I. W., Montoya, J., Plant, A., \& Kordic, T. J. A. o. s. b. (2015). Cell phone internet access, online sexual solicitation, partner seeking, and sexual risk behavior among adolescents. 44(3), 755-763.

Rochmawati, D., \& Arsyati, A. M. J. P. (2019). Gambaran Keterpaparan Media Berkonten Pornografi Pada Anak-Anak Peserta Didik Kelas 4, 5 Dan 6 Di Sdn Kayu Manis 2 Kota Bogor. 2(5), 351-360.

Santoso, E. (2015). Psikologi Remaja. Jakarta : Rajawali Press.

Van Zanten, S., Noel, A., Gresham, L., Boafo, A., Norris, M., Robinson, A., . . Gynecology, A. (2016). Sexual health of adolescents admitted to a psychiatric unit. 29(2), 174.

Winetrobe, H. (2011). Doing well by doing good: Strategic development of socially responsible behavior can build reputation, strengthen knowledge management and drive innovation. Strategic Direction, 27(11), 30-32. doi:10.1108/02580541111177548

Wu, C.-Y., Lee, M.-B., Liao, S.-C., \& Chang, L.-R. J. P. o. (2015). Risk factors of internet addiction among internet users: an online questionnaire survey. 10(10).

Ybarra, M. L., Espelage, D. L., \& Mitchell, K. J. (2014). Differentiating youth who are bullied from other victims of peer-aggression: The importance of differential power and repetition. Journal of Adolescent Health, $55(2)$, 293-300. doi:10.1016/j.jadohealth.2014.02.009 